\title{
Elderly Anticoagulated Patient in General Dental Practice Case Reports from everyday Life
}

\section{G. Wulf (Grit Wulf)}

Dental Practice, SEU PhD Program Emlichheim FR, DE.

\section{E-mail address:}

wulfg@gmail.com

\section{Reprint address:}

\section{Grit Wulf}

Hauptstrasse 33,

88263 Horgenzell

Germany

Source: Clinical Social Work and Health Intervention

Volume: 12

Issue: 3

Pages: $86-92$

Cited references: 37

\section{Reviewers:}

Atilla Czirfusz

Komarno, SK.

Vlastimil Kozon

Allgemeines Krankenhaus - Medizinischer Universitätscampus Vienna, AT.

\section{Keywords:}

Anticoagulated Patient. Dental Practice. Surgical Procedures.

\section{Publisher:}

International Society of Applied Preventive Medicine i-gap

CSWHI 2021; 12(3): 86 - 92; DOI: 10.22359/cswhi_12_3_15 CC Clinical Social Work and Health Intervention

\section{Abstract:}

The anticoagulated elderly patient represents a major and sometimes dreaded challenge for the dentist on a daily basis, as postoperative bleeding can lead to serious problems, especially during dental surgical procedures.

Knowledge of the various anticoagulants with regard to type, mode of action and influences on dental surgical procedures is indispensable for the dentist.

Using case studies from the everyday life of a dental practice in a small town in Thuringia, this problem will be examined in more detail.

\section{Introduction}

Due to demographic change, the number of older people in Europe is steadily increasing. Advances in medicine and pharmacology are leading to longer life expectancy. Advances in dentistry in recent decades have also led to the fact that even very old people still have enough of their own teeth or have excellent prosthetic care on abutment teeth and implants. These patients often have cardiovascular risk factors, which usually require lifelong use of oral anticoagulants and antiplatelet drugs. It is estimated that in Ger- 
many more than one million, approx. $1 \%$ of the population, are treated with anticoagulant drugs. (Al-Nawas, 2018) The older, anticoagulated, previously ill, often insecure and anxious dental patient requires an even more sensitive approach with regard to anamnesis and treatment. It thus represents a major and sometimes dreaded challenge for the dentist on a daily basis, as postoperative bleeding can lead to serious problems, especially in dental surgery. Thus, the dentist is challenged to protect patients from thromboembolic complications on the one hand and to avoid threatening bleeding on the other. (Al-Nawas, 2018) The basic prerequisite for this is knowledge of the type and mode of action of the various anticoagulants, their influence on dental surgical procedures and careful anamnesis and information of the patient.

The problem of the orally anticoagulated patient with his increased risk of suffering a clinically relevant secondary hemorrhage during surgical interventions is currently the subject of controversial discussion; the current literature presents a heterogeneous picture. In general, the risk of a newly occurring thromboembolic event must be weighed against the risk of uncontrollable bleeding as a result of surgery under existing anticoagulation. This individual risk assessment is of particular importance in elective dental procedures. (Kämmerer \& Al-Nawas, 2013)

The author has been working as a dentist in her own practice since obtaining her license to practice dentistry in 1993 at the Friedrich Schiller University of Jena, followed since 1996 by a period of residency at the dental practice van der Veen, Emlichheim,. She has a wealth of professional experience and has been studying the subject in depth since October 2019 as part of her PhD studies at Saint Elisabeth University in Bratislava. In a scientific study, she is comparing the pre- and postoperative management of dental surgery in patients with vitamin $\mathrm{K}$ antagonists and antiplatelet drugs (control group) and patients with NOAKs (comparison group). A high level of knowledge about anticoagulants can thus be considered to be given.

All patients were informed about the anonymous collection of data by means of an information sheet and always agreed, often even were pleased, to be part of a scientific study and willingly gave their consent for photographic docu- mentation. Gender, age, underlying disease, medication, type of surgery, pre- and postoperative procedure and the course of healing were recorded. Within the framework of this study, the following interesting cases were documented, among others, which reflect everyday life in the dental practice.

\section{Oral anticoagulant medication}

\section{Anticoagulants \& antiplatelet agents}

An overview of the current oral drugs for inhibiting blood clotting is shown in the following table (modified from Lambrecht \& von Planta, 2018) and the S3 guidelines of the DGZMK (Deutsche Gesellschaft für Zahn-, Mund- und Kieferheilkunde (DGZMK), Deutsche Gesellschaft für Mund-, Kiefer- und Gesichtschirurgie e.V. (DGMKG) August 2017). It is particularly important for the dentist to assess and evaluate the risk of bleeding before the procedure in order to develop safe management for wound care.

\section{NOAKs}

In the last decade, newly added drugs, NOAKs (= New Oral Anticoagulants) or DOAKs (= Direct Oral Anticoagulants), are increasingly replacing phenprocoumon and warfarin therapy, as these have: a lower risk of intracranial hemorrhage; take effect quickly; have a shorter halflife; is no need to check the INR value. This results in considerable advantages for the patient. They act selectively on a coagulation factor (II or Xa); are at least equally effective with fewer bleeding complications; have fewer interactions with pharmaceuticals or food; do not require regular coagulation checks. (Karow \& Lang-Roth, 2020) On the other hand, the dentist, lacks the parameter to assess the risk of bleeding, (still) the anti-dot (only for Pradaxa, see below, others in testing) and the clinical experience with these drugs. A recent clinical trial looked at simple extractions only and concluded that there was a lower risk of bleeding with the NOAKs compared to warfarin. (Caliskan, Tükel, Benliday, \& Deniz, 2017)

The number of studies on these drugs is still low, the $\mathrm{S} 3$ guidelines of the DGZM are based on few clinical studies and partly contradictory recommendations.

„Therapy should be continued for simple den- 


\begin{tabular}{|c|c|c|c|c|}
\hline $\begin{array}{l}\text { Active } \\
\text { substance }\end{array}$ & Trade name & Indication & Mechanism of action & $\begin{array}{l}\text { Control, } \\
\text { Antidot }\end{array}$ \\
\hline $\begin{array}{l}\text { Phenprocoumon, } \\
\text { Warfarin }\end{array}$ & $\begin{array}{l}\text { Marcumar }^{\circledR}, \\
\text { Falithrom }^{\circledR}, \\
\text { Coumadin }^{\circledR}\end{array}$ & $\begin{array}{l}\text { Thrombosis prophylaxis, } \\
\text { VCF, CHD, embolisms, HI }\end{array}$ & $\begin{array}{l}\text { binding to the enzyme } \\
\text { "vitamin } \mathrm{K} \text { epoxide re- } \\
\text { ductase“ and inhibi- } \\
\text { tion of the carboxyla- } \\
\text { tion of glutamate }\end{array}$ & $\begin{array}{l}\text { INR } \\
\text { Vitamin } \\
\text { K }\end{array}$ \\
\hline Acetylsalicylic acid & $\begin{array}{l}\text { Aspirin }{ }^{\circledR} \\
\text { ASA }^{\circledR}\end{array}$ & $\begin{array}{l}\text { KHK, APVK, thrombosis pro- } \\
\text { phylaxis }\end{array}$ & $\begin{array}{l}\text { COX-1 inhibition and } \\
\text { inhibition thrombox- } \\
\text { ane A2 synthesis }\end{array}$ & none \\
\hline $\begin{array}{l}\text { Thienopyridines } \\
\text { (clopidogrel, Pra- } \\
\text { sugel) }\end{array}$ & $\begin{array}{l}\text { Iscover }^{\circledR} \\
\text { Plavix }^{\circledast} \\
\text { Efient }^{\circledR}\end{array}$ & $\begin{array}{l}\text { PVAK, acute coronary syn- } \\
\text { drome, prevention of } \\
\text { atherothrombotic events } \\
\text { (HI,apoplexy,), often in com- } \\
\text { bination with ASA after fibri- } \\
\text { nolysis, coronary stent } \\
\text { surgery or VHF }\end{array}$ & $\begin{array}{l}\text { Irreversible inhibition } \\
\text { of the platelet ADP- } \\
\text { P2Y12 receptor }\end{array}$ & none \\
\hline Ticacrelor & Brilique $^{\circledR}$ & $\begin{array}{l}\text { Dual therapy in combination } \\
\text { with ASA for the prevention } \\
\text { of atherothrombotic events }\end{array}$ & $\begin{array}{l}\text { Reversible inhibition } \\
\text { of the platelet ADP- } \\
\text { P2Y12 receptor }\end{array}$ & none \\
\hline $\begin{array}{l}\text { Dabigatran } \\
\text { (NOAK) }\end{array}$ & Pradaxa $^{\circledR}$ & $\begin{array}{l}\text { Prevention of venous throm- } \\
\text { boembolic events and } \\
\text { apoplexy, pulmonary em- } \\
\text { bolism, deep vein thrombo- } \\
\text { sis }\end{array}$ & $\begin{array}{l}\text { Competitive and re- } \\
\text { versible binding to } \\
\text { thrombin, blockade of } \\
\text { the conversion of fib- } \\
\text { rinogen to fibrin }\end{array}$ & $\begin{array}{l}\text { Idaru- } \\
\text { cizumab } \\
\text { (Since } \\
\text { 2016) }\end{array}$ \\
\hline $\begin{array}{l}\text { Rivaroxaban } \\
\text { (NOAK) }\end{array}$ & Xarelto ${ }^{\circledR}$ & $\begin{array}{l}\text { Prevention of venous throm- } \\
\text { boembolic events and } \\
\text { apoplexy, pulmonary em- } \\
\text { bolism, deep vein thrombo- } \\
\text { sis }\end{array}$ & $\begin{array}{l}\text { Direct, reversible and } \\
\text { selective inhibition of } \\
\text { factor Xa }\end{array}$ & $\begin{array}{l}\text { Andex- } \\
\text { anet } \\
\text { alfa(Test } \\
\text { phase } \\
\text { Since } \\
\text { 2019) }\end{array}$ \\
\hline $\begin{array}{l}\text { Edoxaban } \\
\text { (NOAK) }\end{array}$ & Lixiana $^{\circledR}$ & $\begin{array}{l}\text { Prevention of apoplexy, sys- } \\
\text { temic embolism, therapy of } \\
\text { deep vein thrombosis and } \\
\text { pulmonary embolism }\end{array}$ & $\begin{array}{l}\text { Direct and reversible } \\
\text { inhibition of factor } \mathrm{Xa}\end{array}$ & $\begin{array}{l}\text { Andex- } \\
\text { anet alfa } \\
\text { (Test } \\
\text { phase } \\
\text { Since } \\
\text { 2019) }\end{array}$ \\
\hline $\begin{array}{l}\text { Apixaban } \\
\text { (NOAK) }\end{array}$ & Eliquis $^{\circledR}$ & $\begin{array}{l}\text { Prevention of venous throm- } \\
\text { boembolic events and } \\
\text { apoplexy, pulmonary em- } \\
\text { bolism, deep vein thrombo- } \\
\text { sis }\end{array}$ & $\begin{array}{l}\text { Direct and reversible } \\
\text { inhibition of factor } \mathrm{Xa}\end{array}$ & $\begin{array}{l}\text { Andex- } \\
\text { anet alfa } \\
\text { (Test } \\
\text { phase } \\
\text { Since } \\
\text { 2019) }\end{array}$ \\
\hline
\end{tabular}


tal surgical procedures in the compressible area". or

"For simple dental surgical procedures in the compressible area, therapy can either be interrupted for a day or also continued“"

(Deutsche Gesellschaft für Zahn-, Mund- und Kieferheilkunde (DGZMK), Deutsche Gesellschaft für Mund-, Kiefer und Gesichtschirurgie (DGMKG), August 2017). (DGMKG), August 2017)

\section{Case presentations}

\section{Case 1 - Phenprocoumon (Falithrom ${ }^{\circledR}$ )}

In an 83-year-old patient who was being anticoagulated with phenprocoumon (Falithrom ${ }^{\circledR}$ ) for heart valve replacement, the endodontically treated, longitudinally fractured tooth 36 had to be removed by a relatively difficult extraction with multiple root separation after administration of cefuroxime 500 for antibiotic prophylaxis and bridging with Clexane in consultation with the general practitioner at an INR value of 1.4. After careful curettage of the alveolus, gelaspon was inserted and the wound edges were fixed with mattress sutures.

The check-up on the next day and the day after showed an extensive cheek hematoma and a regular coagulum, the patient had no pain. 7 days postoperatively, the patient presented for suture removal reporting a "growing blister" in the wound area and nocturnal bleeding for 2 days. There was a massive, exuberant, infected coagulum in the area of alveolus 36.

After renewed antibiotic prophylaxis with cefuroxime 500, preparation of a bleeding plate and conduction anesthesia, the coagulum was removed, the alveolus was curetted, the wound

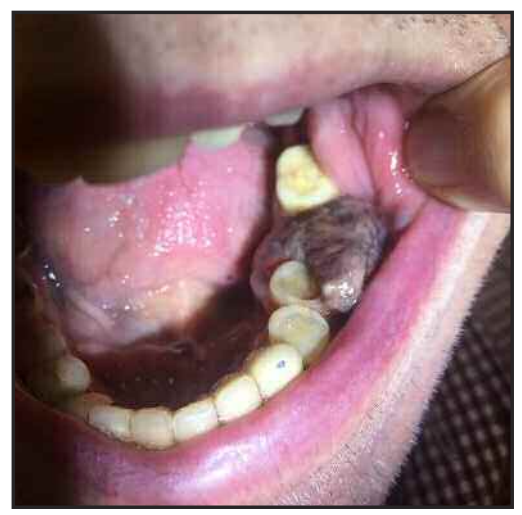

edges were freshened and closed with a mattress suture. The patient was instructed to wear the plate for 10 days postoperatively until the sutures were removed. The wound healing was then without complications, so that the suture material could be removed on the 10th day postoperatively.

\section{Case 2 - Rivaroxaban (Xarelto ${ }^{\circledR}$ )}

A 75-year-old female patient taking Xarelto for condition after pulmonary embolism presented with deeply fractured teeth 24 and 27. On the day of presentation she had not yet taken the drug, an appointment was made for the following day and the patient was instructed not to take Xarelto on that day either. The procedure was known from previous treatments. After gentle removal of the fractured teeth, the wounds were treated with gelaspon and a mattress suture. The healing process was without complications and the suture material was removed on the 7th day postoperatively. Only an extensive hematoma of the cheek caused the patient concern with subjective well-being. These could be eliminated in an informative discussion.

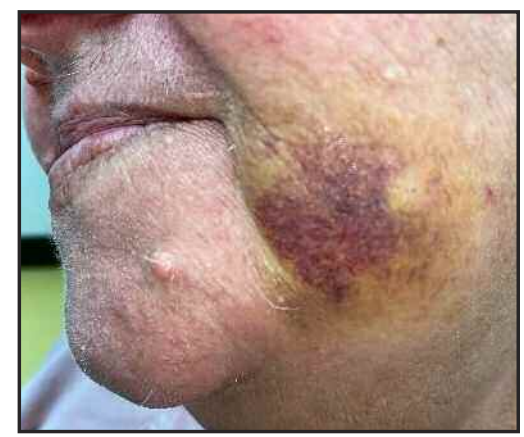

\section{Case 3 - Apixaban (Eliquis ${ }^{\circledR}$ )}

An 87-year-old female patient, who was treated with Eliquis due to a past apoplexy, came to the practice with pain in her right lower jaw. The findings required the removal of the last, partly deeply destroyed teeth $42,43,44$. The existing denture was immediately extended and converted into a wound plate. After consultation with the treating family doctor, Eliquis was discontinued for 24 hours and an extraction appointment was arranged. The removal of the teeth was unproblematic, the alveoli were treated 


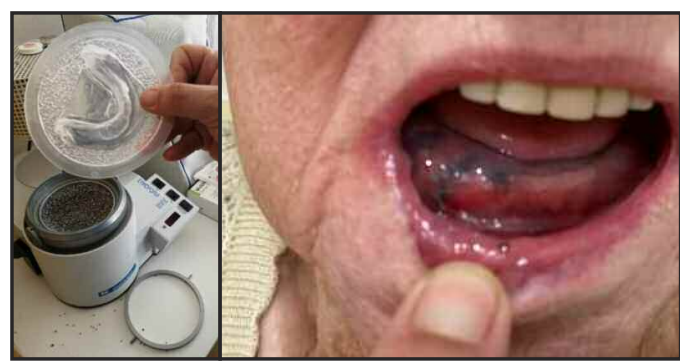

with mattress sutures, the extended denture was fitted, and the patient was instructed to wear it until the follow-up and re-presentation day. The now total, poorly retaining denture in the lower jaw posed a major problem for the patient. Tongue and finger play manipulated the wound area to such an extent that the patient visited the practice again 2 hours postoperatively with secondary bleeding. After anesthesia, the wounds were again excochleated, sutured and gelaspon inserted. The patient was again told to wear the prosthesis at all costs. 7 hours after the operation, the patient came to the consultation for the third time. Without a prosthesis, with her fingers and cellulose in her mouth, which immediately removed the fibrin that had formed. No real postoperative bleeding could be detected. Nevertheless, a bleeding plate was made by means of a miniplast splint and the patient was prescribed prosthesis abstinence. The plate covered the entire lower jaw and thus prevented further tongue and finger play as well as influences from food intake. The further healing process was regular. After removal of the suture material, the prosthesis was reinserted.

\section{Case 4 - Edoxaban (Lixiana ${ }^{\circledR}$ )}

A hitherto unknown 83-year-old patient with pain in the area of the right lower jaw that had been persisting for days presented himself to the agency between the holidays at the turn of the year. The medical history revealed medication with Lixiana due to atrial fibrillation, the treating GP was not available. Together with the patient

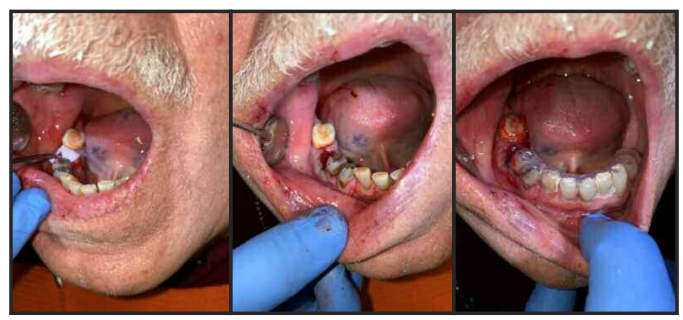

and his wife, the discontinuation of Lixiana and the preparation of a bleeding plate as well as an extraction appointment of the severely periapically inflamed tooth 46 were arranged due to the acute pain.The following day, extraction, careful curettage of the alveolus, insertion of gelaspon, mattress suturing and insertion of the bleeder plate took place. On the 1st day postoperatively, the wound conditions were irritation-free and regular, and the patient was pain-free. The removal of the suture material was done by the family dentist.

\section{Case 5 - Dabigatran (Pradaxa ${ }^{\circledR}$ )}

In a 72-year-old patient treated with Pradaxa due to deep vein thrombosis, the periodontally destroyed teeth $32-42$ had to be removed. As this was a light serial extraction with a low risk of bleeding, it was not necessary to discontinue Pradaxa. After intraligamentary anesthesia, the severely loosened teeth were removed. The existing denture was extended immediately and thus served as a wound plate.

The healing process was completely free of complications.

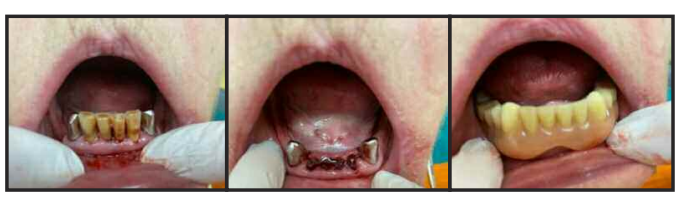

\section{Discussion}

As already mentioned, the elderly anticoagulated patient in the dental practice presents the practitioner with great challenges on a daily basis. If the patient and the medical history are known and there is good cooperation with the general practitioner, the risk of postoperative bleeding after dental surgery can be well assessed and acted upon accordingly. However, cases 1 and 3 in particular show that complications can occur despite careful adherence to the guidelines and lege artis treatment. Both cases kept the entire practice team busy for 5 and 7 hours respectively, thus considerably disrupting the consultation schedule.

In case 1 , it turned out afterwards that the patient had started taking Falithrom again on his own authority on the day after the extraction, but continued to inject Clexane at the same time. A more thorough discussion at the agreed follow- 
up appointment should have brought this to light.

In case 3 , the very elderly patient living alone was completely overwhelmed with the overall situation and only calmed down after the hemophiliac plate was inserted. Extending and remodeling existing dentures in the course of tooth extractions is the usual procedure and leads to success in most cases, as case 5 shows.

\section{Conclusion}

A thorough medical history, patient education and knowledge about the different anticoagulants are indispensable in advance. If possible, contact should be maintained with the attending familiar doctor. It often makes sense, especially with older patients, to include the accompanying person or to question the patient's living conditions.

Extractions should be carried out gently, osteotomies should be avoided and the alveolus should always be thoroughly curetted.

Post-operatively, the dentist has good means of minimizing the risk of post-operative bleeding and wound healing disorders with gelaspon or collagen inserts, adaptive suture techniques and the bleeding plates or remodeled dentures.

The patient should be given a telephone contact at the end of the consultation.

\section{References}

1. CALISKAN M, TÜKEL H C, BENLIDAY E, DENIZ A (11 2017) Is it necessary to alter anticoagulation therapy for tooth extraction in patients taking direct oral anticoagulants? Med Oral Patol Oral Cir Bucal.

2. AL-NAWAS P W (1. 6 2018) Zahnärztliche Chirurgie unter oraler Antikoagulation/Thrombozytenaggregation. zm online.

3. AMK U U (2015) Direkte Orale Antikoagulantien. Ulm.

4. B E, PORODKO M (19 (7-8) 2012) Neue Möglichkeiten zur Antikoagulation bei Vorhofflimmern - Analyse der Studienergebnisse mit Dabigatran und Rivaroxaban. Journal für Kardiologie - Austrian Journal of Cardiology, S. pp. 240-245.

5. BOEDDINGHAUS M (12 2018) ZAHNENTFERNUNG - GRUNDLAGEN UND ALTERNATIVE TECHNIKEN. Der Freie Zahnarzt Wissen kompakt.

6. BUBLITZ R, SOMMER S, WEINGART D,
BÄUERLE K, BOTH A (4 2000) Hämostyptische Wundversorgung bei Marcumarpatienten. Mund-,Kiefer-und Gesichtschirurgie, S. pp. 240-244.

7. BUCH D D (4 2008) Medikamentös verursachte Blutgerinnungsstörungen. ZWP - Zahnärztliche Chirurgie, S. p. 52.

8. DAUBLÄNDER M, KÄMMERER P (3 2012) Hämostase und Antikoagulation. $z m$ online. Deutsche Gesellschaft für Zahn-, Mund- und Kieferheilkunde (DGZMK) Deutsche Gesellschaft für Mund-, Kieferund Gesichtschirurgie e.V. (DGMKG). (August 2017). S3-Leitlinie (Evidenztabellen) Zahnärztliche Chirurgie unter oraler Antikoagulation/ Thrombozytenaggregationshemmung .

9. DRÜKE B (2003) Kompromisse und Grenzen in der zahnärztlichen Chirurgie. Spitta.

10. EISELE R, MELZER N, BRAMLAGE P (2014) Perioperatives Gerinnungsmanagement bei oraler Antikoagulation. Der Chi$\operatorname{rurg}(85)$, S. pp. 513-519.

11. ELVERS D, SCHMIDT H (12 2018) NAHTMATERIAL UND NAHTTECHNIKEN. Der Freie Zahnarzt Wissen kompakt.

12. FIALK A F, KRAMER F (82 2006) Zahnärztliche Eingriffe bei oral antikoaguliertenPatienten: Aktuelle Leitlinien und deren klinischeRelevanz für die Kooperation von Haus- und Zahnarzt. Allgemeinmedizin, S. pp. 562-566.

13. GRÖTZ D T P (17. 7 2019) Der Umgang mit antikoagulierten Patienten. zmk-aktuell online.

14. HEMELIK M, W G (10 2006) Zahnextraktion unter Medikation mit Aceetylsalicylsäure (ASS). Mund-Kiefer-Gesichtschirurgie.

15. HOFFMEISTER H, BODE C, DARIUS H, HUBER K, RYBAK K, SILBER S (4 2010). Unterbrechung antithrombotischer Behandlung (Bridging) bei kardialen Erkrankungen. Der Kardiologe, S. pp. 365-374.

16. KÄMMERER P, AL-NAWAS B (7 2013) Oral antikoagulierte Patienten unter zahnärztlich-chirurgischer Behandlung. Wissen compact, S. 3-11.

17. KAROW T, LANG-ROTH R (2020) Allgemeine und spezielle Pharmakologie und Toxikologie.

18. KIRAMIRA D, AL-NAWAS B (12 2018) 
DER KORREKTE EINSATZ VON HEBELN UND PERIOTOMEN BEI DER ZAHNENTFERNUNG. Der Freie Zahnarzt Wissen komakt.

19. KOSCIELNY J (8 2017) [Dual Antiplatelet Therapy in the Perioperative Period - To Continue or Discontinue Treatment?] . Dtsch Med Wochenschr.

20. KUNKEL M (5 2012) Zur „Sicherheit,, von Zahnextraktionen unter kontinuierlicher einfacher oder kombinierter Therapie mit Plättchenaggregationshemmern. Der MKG Chirurg, S. pp. 141-142.

21. LAMBRECHT J, VON PLANTA M (2018) Zahnärztliche Risikopatienten. Quintessence Publishing Deutschland.

22. MERTEN H, MAZUREK M, GRUBER R, LUDWIG A (2 2004) Postoperative Nachblutungsrate antikoagulierter Patienten nach oralchirurgischen Eingriffen. Quintessenz, S. pp. 113-122.

23. MOLLEN I, FILLIPI A, KÜHL S (3 2014. Alveolenstabilisierung nach ZahnentfernungVor- und Nachteile. Implantologie, S. pp. 299-306.

24. NIEDERER A, WUILLEMIN W, MOERLOOSE P (4 2001) Orale Antikoagulation:Praktisches Vorgehen. CURRICULUM Schweiz Med Forum, S. pp. 425-430.

25. SCHEER M (59 2004) Zahnäztlich-Chirurgische Behandlung von oral antikoagulierten Patienten unter Einsatz eines beschichteten Kollagenvlieses. Deutsches Zahnärzteblatt, S. pp. 220-226.

26. SCHEER M, NEUGEBAUER, J., \& ZÖLLER, J. (4 2007). Blutstillung in der zahnärztlichen Chirurgie. ZWP, S. pp. 64-68.

27. SCHMELZEISEN R (57 2002) Wissenschaftliche Stellungnahme der DGZMK: Zahnärztliche Chirurgie bei Patienten mit Antikoagulantientherapie. Deutsches Zahnärzteblatt, S. pp. 140-141.

28. SCHMIDLIN P, JUNG R, SCHUG J (114 2004) Alveolarkammpräventionnach Zahnextraktion - eine Literaturübersicht. Schweiz Monatsschr Zahnmed, S. pp. 328336.

29. SCHNEIDER D, KÄMMERER P (11 2017) Wie Sie Nachblutungen nach Zahn-OPs vermeiden. zm online.

30. SCHUBERT J, REPPEL R (108 1999) Kom- plikationen bei zahnärztlichen Eingriffen. ZWR, S. pp. 82-84.

31. SCHULZ S (47 1992) Zum Blutungsrisiko nach Zahnextraktionen unter Dauermedikation von Antikoagulantien. Deutsches Zahnärzteblatt, S. pp. 238-239.

32. SCHWABE S (2006) Antikoagulantien und Thrombocytenaggregationshemmer. Berlin: Springer Verlag.

33. SMEETS R, HENNINGSEN A, MADANI E (12 2018) „CHIRURGISCHE GRUNDLAGEN - INSTRUMENTE, SCHNITTFÜHRUNG, LAPPENDESIGN,,. Der Freie Zahnarzt Wissen komakt.

34. STIMMELMAYR M, STANGL M, GERNET W, EDELHOFF D, GÜTH J, BEUER F (6 2010) Biologie der Alveolen heilung und chirurgische Maßnahmen zum Alveolen- und Kammerhal. DZZ Deutsche zahnärztliche Zeitung, S. pp. 294-303.

35. THIEM D, KÄMMERER P (10 2019) Zahnärztlich-chirurgisches Vorgehen bei Patienten unter oraler Blutgerinnungshemmung. wissen compact, S. 185-198. Universitätsklinikum Ulm, Arbeitsgruppe Gerinnung der Arzneimittelkommission,

36. FISCHER S (08.12.2015) Direkte orale Antikoagulantien. Ulm.

37. VETTER C (Heft 24 2011) Gerinnungshemmung heißt erhöhtes Blutungsrisiko. zm online. 